\title{
Leptospirosis in febrile patients with suspected diagnosis of dengue fever
}

\author{
Juana del Valle-Mendoza ${ }^{1,2^{*}+}$ (D), Carlos Palomares-Reyes ${ }^{1 \dagger}$, Hugo Carrillo-Ng ${ }^{2,3}$, Yordi Tarazona-Castro ${ }^{1,2 \dagger}$, \\ Sungmin Kym ${ }^{4}$, Miguel Angel Aguilar-Luis ${ }^{1,2}$, Luis J. del Valle ${ }^{5}$, Ronald Aquino-Ortega ${ }^{1,2}$, \\ Johanna Martins-Luna ${ }^{1,2}$, Isaac Peña-Tuesta ${ }^{1,2}$ and Eduardo Verne and Wilmer Silva-Caso $12^{2 *}$
}

\begin{abstract}
Objective: This study was carried out to determine the prevalence of leptospirosis among febrile patients with a suspicious clinical diagnosis of dengue fever in northern Peru.

Results: A total of 276 serum samples from patients with acute febrile illness (AFI) and suspected diagnosis for dengue virus (DENV) were analyzed. We identified an etiological agent in 121 (47.5\%) patients, DENV was detected in $30.4 \%$ of the cases, leptospirosis in $11.2 \%$ and co-infection by both pathogens was observed in $5.9 \%$ of the patients. In this study the most common clinical symptoms reported by the patients were: headache $89.1 \%$, myalgias $86.9 \%$ and arthralgias $82.9 \%$. No differences in symptomatology was observed among the different study groups.
\end{abstract}

Keywords: Acute febrile illnesses, Leptospirosis, DENV, Tropical disease

\section{Introduction}

Leptospirosis is a tropical disease caused by spirochetes of the genus Leptospira spp. [1]. It is a zoonotic and waterborne disease that is endemic in many developing countries $[1,2]$. Its transmission occurs by direct or indirect exposure to urine of infected reservoir host animals $[2,3]$. Leptospirosis is considered the most neglected tropical disease and the leading zoonotic cause of morbidity and mortality [2, 4], accounting for 1.03 million human cases every year and 58,000 deaths worldwide $[4,5]$. Dengue fever is an arboviral disease caused by the infection of any of the four dengue virus serotypes, denominated as DENV $1-4[6,7]$. It is the most important mosquito-borne disease worldwide, which is transmitted by the Aedes aegypti mosquito [6]. This virus is

\footnotetext{
*Correspondence: juana.delvalle@upc.pe; wilmer.silva@upc.pe; gian_ will@hotmail.com

†Juana del Valle-Mendoza, Carlos Palomares-Reyes and Yordi TarazonaCastro authors contributed equally to this article

${ }^{1}$ School of Medicine, Research and Innovation Center of the Faculty of Health Sciences, Universidad Peruana de Ciencias Aplicadas, Lima, Peru Full list of author information is available at the end of the article
}

responsible for approximately 390 million infections every year and 25,000 deaths worldwide, affecting particularly tropical and subtropical regions $[8,9]$. Both pathogens are common causes of acute febrile illnesses (AFI) in many developing countries $[10,11]$ and have the potential to cause large outbreaks due to heavy rainfall and flooding [11]. Furthermore, they have reemerged as important public health problems due to recent extreme weather events, human migration, urbanization and climate change $[2,8,10,12]$.

Leptospirosis typically causes two phases of infection: a mild anicteric phase in $80-90 \%$ of the patients and a classical icteric phase in the rest of the patients [2, 3 , 13]. The anicteric form usually causes a mild febrile illness with minimal or no clinical manifestations, and the majority of patients display a nonspecific febrile syndrome undistinguishable from other causes of AFI [2, $3,14]$. However, a group of patients develop an icteric severe form, which include hepatic, pulmonary and acute renal failure known as Weill's disease [13, 14]. In a similar way, most of the patients with DENV infection present with a broad clinical spectrum, ranging from a

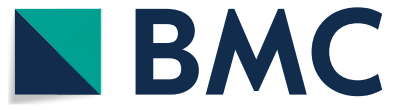

(c) The Author(s) 2021. This article is licensed under a Creative Commons Attribution 4.0 International License, which permits use, sharing, adaptation, distribution and reproduction in any medium or format, as long as you give appropriate credit to the original author(s) and the source, provide a link to the Creative Commons licence, and indicate if changes were made. The images or other third party material in this article are included in the article's Creative Commons licence, unless indicated otherwise in a credit line to the material. If material is not included in the article's Creative Commons licence and your intended use is not permitted by statutory regulation or exceeds the permitted use, you will need to obtain permission directly from the copyright holder. To view a copy of this licence, visit http://creativeco mmons.org/licenses/by/4.0/. The Creative Commons Public Domain Dedication waiver (http://creativecommons.org/publicdomain/ zero/1.0/) applies to the data made available in this article, unless otherwise stated in a credit line to the data. 
mild fever to classical dengue fever with hemorrhage and/or shock [6, 7].

The overlapping spectrum of signs and symptoms makes the diagnosis difficult, particularly in the acute phase of the disease [15-17]. The differential diagnosis of leptospirosis and dengue fever remains a major challenge for surveillance programs in resource-limited settings, as both have similar clinical profiles and seasonal onset [16]. Usually, DENV is thought to be the first probable diagnosis in patients with AFI in endemic areas. Moreover, the lack of symptom specificity, lack of appropriate diagnostic methods, and passive characteristics of the surveillance programs in affected regions may underestimate leptospirosis burden [16-18]. However, the diagnosis of one pathogen does not exclude the other, as co-infection between both have been described with a prevalence of $3.4 \%$ and $4.1 \%[10,15]$.

The study of the pathogens responsible for AFI in Peru is crucial to understand their real impact in the population and to guide local clinicians to perform an accurate diagnosis. We hypothesize that many cases initially cataloged as dengue fever, may be in fact leptospirosis. Therefore, this study aimed to detect the presence leptospirosis in patients with AFI and a suspected diagnosis of dengue virus.

\section{Main text \\ Methods \\ Study site}

We performed a consecutive cross-sectional study in Piura, Peru between March and August of 2016 within eight urban primary health care centers from the "Regional Directive of Health of Piura". The region of Piura is located in the northern coast of Peru, sharing boundaries to the north with Ecuador. Piura has an estimated population of $1,856,809$ inhabitants.

\section{Patients}

A total of 276 patients were enrolled from March to August 2016 as part of the national dengue surveillance program. The inclusion criteria consisted of patients attending outpatient health centers with acute febrile illness (axillary temperature equal or greater than $38^{\circ} \mathrm{C}$ in the previous 7 days) and a clinical suspicion of dengue fever according to the Peruvian Ministry of Health guidelines, which consist of AFI plus two of the following symptoms: arthralgias, myalgias, headache, retro ocular pain, lumbar pain and rash. Patients with an identifiable source of infection such as upper respiratory infection, urinary tract infection, among others were excluded.

\section{Samples}

One serum sample per patient was collected by using Vacuette ${ }^{\circledR}$ TUBE Serum Separator Clot Activator (Vacuette, Greiner Bio-One, Kremsmünster, Austria). After collection, all samples were centrifuged at $3000 \mathrm{rpm}$ for $5 \mathrm{~min}$ and the serum is stored at $-80{ }^{\circ} \mathrm{C}$ to perform molecular assays.

\section{Detection of Leptospira IgM antibodies based-ELISA assay}

Participants with a positive IgM ELISA sample, were considered positive for leptospirosis infection. Levels of antibodies were quantified using High Sensitivity Leptospira ELISA Kit (Abcam, United State). Each serum sample was run in duplicate, in accordance with the manufacturer's instructions.

\section{Real-time RT-PCR assay detection DENV serotypes with the TaqMan probe}

RNA extraction was performed from $200 \mu \mathrm{L}$ of the serum samples with the High Pure RNA Isolation Kit (Roche Applied Science, Mannheim, Germany), according to the manufacturer's instructions. DENV amplification was performed using the Transcriptor High Fidelity cDNA Synthesis Kit (Roche Applied Science, Mannheim, Germany) and the primers, the probe and conditions were previously described [19]. All the procedure was performed in Light Cycler ${ }^{\circledR} 2.0$ Instrument and data was analyzed with the LightCycler ${ }^{\circledR}$ Software 4.1 (Roche Diagnostic, Deutschland-Mannheim, Germany).

\section{Ethics statement}

The study protocol was approved by the Research Ethics Board of the Hospital Regional Docente de Cajamarca, Cajamarca, Peru. The samples were obtained in the context of the epidemiological/syndromic surveillance program according to the health directives of the National Center for Epidemiology, Disease Control and Prevention of the Ministry of Health of Peru.

\section{Statistical analysis}

The collected data were reported as frequencies and percentages. Chi square test was performed to estimate statistical difference between the variables, a value of $\mathrm{P}<0.05$ was considered significant. All analyses and figures were processed in the GraphPad Prism 9 program (San Diego, CA).

\section{Results}

A total of 276 febrile patients with a clinical suspicion of dengue fever were studied from March to August 2016. Patients were grouped by ages, the majority of patients 
corresponded to the group between 20 and 44 years old with $33.3 \%$ cases, followed by the group between 5 and 19 years old with $26.5 \%$ the group between 45 and 59 years old and the one of $60+$ were both $17.4 \%$, respectively. There were no differences between gender with $143(51.8 \%)$ female and 133 (48.2\%) male patients (Table 1).

We identified an etiological agent in 121 (47.5\%) patients of all clinically diagnosed AFI and a suspected diagnosis of dengue fever. The majority of the patients were diagnosed with DENV accounting for 84 cases (30.4\%), infection by only leptospirosis was detected in 31 patients $(11.2 \%)$ and co-infection by both pathogens was observed in 16 (5.9\%) of the patients (Fig. 1A). Of the total population, a pathogen could not be identified in 156 patients. Among the 121 patients with an etiological agent identified, the vast majority were indeed dengue infection with a $64 \%$. However, leptospirosis and coinfections were detected in approximately a third of the patients with $24 \%$ and $12 \%$, respectively (Fig. 1B).
In this study the most common clinical symptoms reported by all the patients were: headache $89.1 \%$, myalgias $86.9 \%$ and arthralgias $82.9 \%$. Patients infected only by dengue virus reported $85.1 \%$ myalgia, $83.9 \%$ headache and $81.6 \%$ arthralgia. In the case of patients with only leptospirosis infection the most frequent clinical symptoms were $96.7 \%$ headache, $90.3 \%$ arthralgias and $87.1 \%$ myalgias. Surprisingly, the $100 \%$ of the patients with coinfection reported headaches and myalgias, and $87.5 \%$ arthralgias (Table 2).

\section{Discussion}

Acute febrile illness (AFI) encompasses a broad spectrum of infectious causes; however, it remains poorly characterized in tropical regions of the developing world [20-22]. Commonly, health care providers in developing countries find themselves in the need to apply syndromebased treatment protocols, due to the lack of diagnostic tests $[20,21]$. Dengue virus (DENV) and leptospirosis are among the most common causes of AFI $[10,15,17$,

Table 1 Demographic characteristics in AFI patients with dengue, leptospirosis and co-infection

\begin{tabular}{|c|c|c|c|c|c|}
\hline Characteristics & Total cases n (\%) & Dengue $\mathrm{n}(\%)$ & Leptospira n (\%) & Co-infection n (\%) & P-value \\
\hline \multicolumn{6}{|l|}{ Age } \\
\hline $0-4$ & $15(5.4)$ & $4(4.6)$ & $0(0.0)$ & $1(6.3)$ & 0.42 \\
\hline $5-19$ & $73(26.5)$ & $13(14.9)$ & $8(25.8)$ & $2(12.5)$ & 0.37 \\
\hline $20-44$ & $92(33.3)$ & $29(33.3)$ & $15(48.4)$ & $6(37.5)$ & 0.40 \\
\hline $45-59$ & $48(17.4)$ & $14(16.7)$ & $5(16.1)$ & $4(25.0)$ & 0.70 \\
\hline $60+$ & $48(17.4)$ & $24(28.6)$ & $3(9.7)$ & $3(18.7)$ & 0.09 \\
\hline \multicolumn{6}{|l|}{ Gender } \\
\hline Male & $133(48.2)$ & $42(50.0)$ & $12(38.7)$ & $9(56.3)$ & 0.44 \\
\hline Female & $143(51.8)$ & $42(50.0)$ & $19(61.3)$ & $7(43.7)$ & 0.44 \\
\hline Total & $276(100.0)$ & $84(100.0)$ & $31(100.0)$ & $16(100.0)$ & \\
\hline Positive cases (\%) & 47.5 & 30.4 & 11.2 & 5.9 & \\
\hline Cl 95\% & $42.5-52.5$ & $25.0-35.8$ & $7.5-14.9$ & $3.2-8.6$ & \\
\hline
\end{tabular}

\section{A Etiological agent}

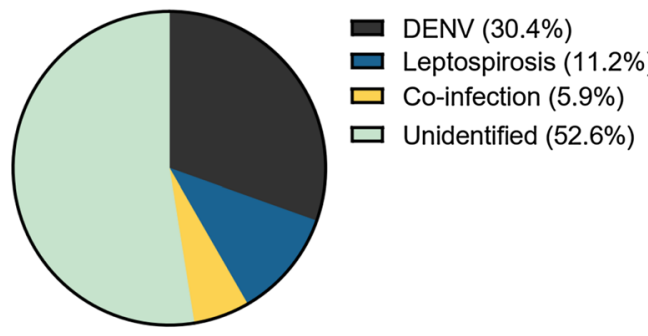

Total patients $=\mathbf{2 7 6}$

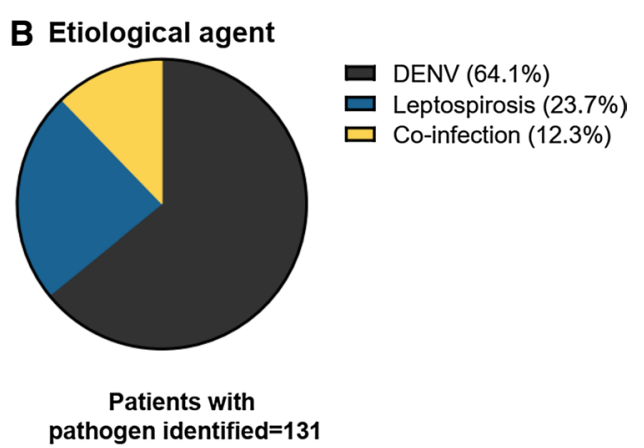

pathogen identified $=131$

Fig. 1 Frequency of etiological agents identified in patients with AFI. A Frequency of the etiological agents detected in the total population. B Distribution of the pathogens identified in the group of positive patients 
Table 2 Clinical characteristics in patients with dengue, Leptospira and co-infections

\begin{tabular}{|c|c|c|c|c|c|c|c|c|}
\hline \multirow[t]{2}{*}{ Clinical symptoms } & \multicolumn{2}{|c|}{ Total cases } & \multicolumn{2}{|c|}{ Dengue } & \multicolumn{2}{|c|}{ Leptospira } & \multicolumn{2}{|c|}{ Co-infection } \\
\hline & $n=276$ & $\%$ & $n=84$ & $\%$ & $\mathrm{n}=31$ & $\%$ & $\mathrm{n}=16$ & $\%$ \\
\hline Headache & 246 & 89.1 & 73 & 83.9 & 30 & 96.7 & 16 & 100.0 \\
\hline Myalgia & 240 & 86.9 & 74 & 85.1 & 27 & 87.1 & 16 & 100.0 \\
\hline Arthralgias & 229 & 82.9 & 71 & 81.6 & 28 & 90.3 & 14 & 87.5 \\
\hline Retroocular pain & 199 & 72.1 & 60 & 69.0 & 25 & 80.6 & 13 & 81.3 \\
\hline Hyporexia & 177 & 64.1 & 45 & 51.7 & 21 & 67.7 & 11 & 68.8 \\
\hline Nauseas/vomiting & 137 & 49.6 & 40 & 46.0 & 13 & 41.9 & 7 & 43.8 \\
\hline Low back pain & 158 & 57.2 & 54 & 62.1 & 14 & 45.2 & 15 & 93.8 \\
\hline Odynophagia & 105 & 38.0 & 27 & 31.0 & 11 & 35.5 & 5 & 31.3 \\
\hline Rash & 60 & 21.7 & 16 & 18.4 & 9 & 29.0 & 1 & 6.3 \\
\hline Abdominal pain & 14 & 5.1 & 3 & 3.4 & 1 & 3.2 & 1 & 6.3 \\
\hline Platelet decrease & 6 & 2.2 & 1 & 1.1 & 0 & 0 & 1 & 6.3 \\
\hline Petechiae & 10 & 3.6 & 1 & 1.1 & 1 & 3.2 & 1 & 6.3 \\
\hline Epistaxis & 4 & 1.4 & 0 & 0 & 0 & 0 & 0 & 0 \\
\hline Gingivorrhagia & 1 & 0.4 & 0 & 0 & 0 & 0 & 0 & 0 \\
\hline Hemoptisis & 1 & 0.4 & 0 & 0 & 0 & 0 & 0 & 0 \\
\hline Chest pain & 3 & 1.1 & 1 & 1.1 & 0 & 0 & 0 & 0 \\
\hline Altered mental status & 1 & 0.4 & 1 & 1.1 & 0 & 0 & 0 & 0 \\
\hline Increase in hematocrit & 5 & 1.8 & 1 & 1.1 & 0 & 0 & 0 & 0 \\
\hline Jaundice & 1 & 0.4 & 0 & 0 & 0 & 0 & 1 & 6.3 \\
\hline Gynecorrhagia & 1 & 0.4 & 0 & 0 & 1 & 3.2 & 0 & 0 \\
\hline Melaena & 1 & 0.4 & 0 & 0 & 0 & 0 & 0 & 0 \\
\hline Decrease diuresis & 1 & 0.4 & 0 & 0 & 0 & 0 & 0 & 0 \\
\hline Echimosis & 1 & 0.4 & 0 & 0 & 0 & 0 & 0 & 0 \\
\hline Persistent vomiting & 5 & 1.8 & 1 & 1.1 & 0 & 0 & 1 & 6.3 \\
\hline Hypothermia & 3 & 1.1 & 0 & 0 & 0 & 0 & 0 & 0 \\
\hline Lipotimia & 3 & 1.1 & 0 & 0 & 0 & 0 & 0 & 0 \\
\hline Hypotension & 1 & 0.4 & 0 & 0 & 0 & 0 & 0 & 0 \\
\hline Chills & 2 & 0.7 & 1 & 1.1 & 0 & 0 & 0 & 0 \\
\hline Cough & 1 & 0.4 & 1 & 1.1 & 0 & 0 & 0 & 0 \\
\hline
\end{tabular}

20-22]. They often pose a diagnostic challenge for health care providers in tropical and subtropical regions; therefore, we performed the first study in northern Peru to characterize the burden of leptospirosis infection among patients seeking for medical care with a dengue-like illness.

We evaluated 276 patients in outpatient health centers for the presence of leptospirosis in patients with a probable diagnosis of DENV, in the context of the dengue epidemiological surveillance. An etiological agent was detected in $47.5 \%$ of the patients. Out of the total samples $30.4 \%$ tested positive for DENV as a single infectious agent by RT-PCR, $11.2 \%$ were positive for leptospirosis as a single infectious agent by detection of IgM ELISA and $5.9 \%$ were infected by both pathogens. We could highlight that accurate and reliable techniques for detection of the pathogens were performed, such as real time RT-PCR in the case of DENV and detection of IgM ELISA-based assay in acute sera of leptospirosis [6, 14].

We found an important frequency of leptospirosis among febrile patients with a probable diagnosis of dengue, with a frequency of $17.1 \%$ (11.2\% as single infection and $5.9 \%$ as co-infection) in the total samples. Moreover, among the 121 patients in which an etiological agent was identified, at least a third of the patients had the diagnosis of leptospirosis. If fact, many regions in Peru are considered endemic and hyper-endemic for this disease, particular due to occupational exposure [23-25]. The largest study of leptospirosis in Peru was carried out between 1994 and 2004, identifying this pathogen in 18 of the 24 regions of Peru, being predominantly in the amazon [25]. However, most of the cases detected were severe and/or icteric forms of the disease, therefore, milder cases might have been left out. Also, a prevalence 
of leptospirosis ranging from 11.1 to $36.6 \%$ have been reported in patients with AFI in Peru [26].

Previous studies have also reported the detection of leptospirosis among patients with dengue-like symptoms in other settings. Dircio-Montes, et al. established the prevalence of leptospirosis in patients with an initial diagnosis of dengue, they concluded that at least a sixth part of the cases were leptospirosis infection and should have been treated with antibiotics [27]. Libraty et al. also reported that leptospirosis accounted for 19\% of dengue suspected patients that tested negative for DENV [18]. Other studies have reported a lower prevalence of leptospirosis among dengue suspected patients ranging from 5 to $7.35 \%[28,29]$. Moreover, it has been reported that many leptospirosis cases may go under recognized during dengue outbreaks [30,31].

On the other hand, we could not determine the etiological agent in half of the patients studied. The detection of two pathogens of interest was evaluated, however, other emerging and re-emerging infectious pathogens causative of AFI have become more prevalent in our country, such as Zika virus, Chikungunya virus, Mayaro virus, Oropouche virus, Rickettsia spp, Bartonella spp, among others [32-34].

Clinical characteristics were also evaluated regarding the etiology of the infection. We could observe the presence of unspecific symptoms among all groups. The three groups of patients reported similar frequencies of headache, myalgias and arthralgias as predominant symptoms accompanying fever, we could observe the overlapping signs and symptoms that patients with leptospirosis and dengue may present. This highlights the need for available diagnostic tests to accurate diagnose leptospirosis in patients with probable dengue diagnosis. However, we observed that $100 \%$ of the patients with co-infections reported headache and myalgia, also a high frequency of arthralgias. Also, the only case of jaundice reported in our study correspond to this group. This is in agreement with previous studies, which have reported fatal cases and severe disease when both pathogens are present [35].

In conclusion, we found that an etiological diagnosis could be achieved in $47.5 \%$ of the total cases. Leptospirosis was identified in $17.1 \%(11.2 \%$ as single infection and $5.9 \%$ as co-infection) of the patients with suspected dengue diagnosis. Accurate and early diagnostic tests are crucial as clinical signs and symptoms may be overlapping. It is of great importance to differentiate these two pathogens as patients with leptospirosis may benefit from antibiotic use.

\section{Limitations}

Our main limitation is that we could not identify the etiological agent responsible for the febrile illness in nearly half of the patients and other pathogens could be involved, however, we were focused on two pathogens of interest. Another limitation is that not all of the patients with AFI could attend to outpatient health centers and we could have missed more severe cases.

\section{Abbreviations \\ AFI: Acute febrile illness; DENV: Dengue virus; RT-PCR: Reverse transcription polymerase chain reaction.}

\section{Acknowledgements}

We thank the staff of the health network from Chulucanas-Piura, Peru.

\section{Authors' contributions}

JdVM, LJdV, EV and SK designed the study protocol. JdVM, CPR, YTC, MAAL, $J M L$, IPT and WSC performed the RT-PCR and ELISAS. JdVM, LJdV and SK were responsible for obtaining funding and laboratory work supervision. MAAL, WSC, YTC, HCN, and RAO was responsible for the clinical assessment, samples collection and database completion. JdVM, HCN, SK, EV and LdV were responsible to draft the manuscript. All authors critically revised the manuscript for intellectual content. All authors read and approved the final manuscript.

\section{Funding}

This work was supported by Incentives for Research of the Universidad Peruana de Ciencias Aplicadas, Grant No. UPC-A-081-2020, Lima-Peru. This research was supported by the Bio \& Medical Technology Development Program of the National Research Foundation (NRF) funded by the Korean government (MSIT) (No. 2016M3A9B8942289).

\section{Availability of data and materials}

Abstraction format used in the study and dataset are available and accessible from the corresponding author upon request in the link: https://figshare. com/s/a21c004df98dce729476

\section{Declarations}

\section{Ethics approval and consent to participate}

The study protocol was approved by the Research Ethics Board of the Hospital Regional Docente de Cajamarca, Cajamarca, Peru. The samples were obtained in the context of the epidemiological/syndromic surveillance program according to the health directives of the National Center for Epidemiology, Disease Control and Prevention of the Ministry of Health of Peru.

\section{Consent for publication}

Not applicable.

\section{Competing interests}

On behalf of all authors, the corresponding author states that there are no conflicts of interest or funding related to this study.

\section{Author details}

${ }^{1}$ School of Medicine, Research and Innovation Center of the Faculty of Health Sciences, Universidad Peruana de Ciencias Aplicadas, Lima, Peru. ${ }^{2}$ Laboratorio de Biologia Molecular, Instituto de Investigación Nutricional, Lima, Peru. ${ }^{3}$ Facultad de Medicina Alberto Hurtado, Universidad Peruana Cayetano Heredia, Lima, Perú. ${ }^{4}$ Division of Infectious Disease, Department of Internal Medicine, Chungnam National University School of Medicine, Daejeon, Korea. ${ }^{5}$ Barcelona Research Center for Multiscale Science and Engineering, Departament D'Enginyeria Química, EEBE, Universitat Politècnica de Catalunya (UPC), Barcelona, Spain.

Received: 21 February 2021 Accepted: 20 May 2021

Published online: 29 May 2021 


\section{References}

1. Guernier V, Goarant C, Benschop J, Lau CL. A systematic review of human and animal leptospirosis in the Pacific Islands reveals pathogen and reservoir diversity. PLoS Negl Trop Dis. 2018;12(5):e0006503.

2. Karpagam KB, Ganesh B. Leptospirosis: a neglected tropical zoonotic infection of public health importance-an updated review. Eur J Clin Microbiol Infect Dis. 2020. https://doi.org/10.1007/s10096-019-03797-4.

3. Haake D, Levett P. Leptospirosis in humans. Curr Top Microbiol Immunol. 2015:387:65-97.

4. Costa F, Hagan J, Calcagno J, Kane M, Torgerson P, Martinez-Silveira M, et al. Global morbidity and mortality of leptospirosis: a systematic review. PLOS Negl Trop Dis. 2015;9(9):e0003898.

5. Torgerson P, Hagan J, Costa F, Calcagno J, Kane M, Martinez-Silveira M, et al. Global burden of leptospirosis: estimated in terms of disability adjusted life years. PLOS Negl Trop Dis. 2015;9(10):e0004122.

6. Muller DA, Depelsenaire AC, Young PR. Clinical and laboratory diagnosis of dengue virus infection. J Infect Dis. 2017;215(suppl_2):S89-95.

7. Guzman M, Gubler D, Izquierdo A, Martinez E, Halstead S. Dengue infection. Nat Rev Dis Primers. 2016. https://doi.org/10.1038/nrdp.2016.55.

8. Bhatt S, Gething PW, Brady OJ, Messina JP, Farlow AW, Moyes CL, et al. The global distribution and burden of dengue. Nature. 2013;496(7446):504-7.

9. St. John A, Rathore A. Adaptive immune responses to primary and secondary dengue virus infections. Nat Rev Immunol. 2019;19(4):218-30.

10. Suppiah J, Chan SY, Ng MW, et al. Clinical predictors of dengue fever coinfected with leptospirosis among patients admitted for dengue fever-a pilot study. J Biomed Sci. 2017;24(1):40

11. Moreira J, Bressan CS, Brasil P, Siqueira AM. Epidemiology of acute febrile illness in Latin America. Clin Microbiol Infect. 2018;24(8):827-35.

12. Decker K. Dengue fever: re-emergence of an old virus. J Nurse Pract. 2012;8(5):389-93.

13. De Brito T, Silva AMGD, Abreu PAE. Pathology and pathogenesis of human leptospirosis: a commented review. Rev Inst Med Trop Sao Paulo. 2018;60:e23.

14. Musso D, La Scola B. Laboratory diagnosis of leptospirosis: a challenge. J Microbiol Immunol Infect. 2013;46(4):245-52.

15. Sachu A, Madhavan A, Vasudevan A, Vasudevapanicker J. Prevalence of dengue and leptospirosis co-infection in a tertiary care hospital in south India. Iran J Microbiol. 2018;10(4):227-32.

16. Fontes R, Cavalcanti L, Oliveira A, Bezerra L, Gomes A, Colares J, et al. A new possibility for surveillance: do we identify all cases of leptospirosis. Rev Inst Med Trop Sao Paulo. 2015;57(5):443-6.

17. Bruce MG, Sanders EJ, Leake JA, et al. Leptospirosis among patients presenting with dengue-like illness in Puerto Rico. Acta Trop. 2005;96(1):36-46

18. Libraty D, Myint K, Murray C, Gibbons R, Mammen M, Endy T, et al. A comparative study of leptospirosis and dengue in Thai children. PLoS Negl Trop Dis. 2007. https://doi.org/10.1371/journal.pntd.0000111.

19. Alva-Urcia C, Aguilar-Luis MA, Palomares-Reyes C, Silva-Caso W, Suarez-Ognio L, Weilg P, Manrique C, Vasquez-Achaya F, Del Valle LJ, Del Valle-Mendoza J. Emerging and reemerging arboviruses: a new threat in Eastern Peru. PLoS ONE. 2017. https://doi.org/10.1371/journal.pone. 0187897

20. Robinson ML, Manabe YC. Reducing uncertainty for acute febrile illness in resource-limited settings: the current diagnostic landscape. Am J Trop Med Hyg. 2017:96(6):1285-95. https://doi.org/10.4269/ajtmh.16-0667.
21. Lorenzi OD, Gregory CJ, Santiago LM, et al. Acute febrile illness surveillance in a tertiary hospital emergency department: comparison of influenza and dengue virus infections. Am J Trop Med Hyg. 2013;88(3):472-80.

22. Manock SR, Jacobsen KH, de Bravo NB, Russell KL, Negrete M, Olson JG, Sanchez JL, Blair PJ, Smalligan RD, Quist BK, Espín JF, Espinoza WR, MacCormick F, Fleming LC, Kochel T. Etiology of acute undifferentiated febrile illness in the Amazon basin of Ecuador. Am J Trop Med Hyg. 2009;81(1):146-51.

23. Alarcón-Villaverde JO, Romani-Romani F, Tejada Romina A, Wong-Chero P, Céspedes-Zambrano M. Seroprevalencia de leptospirosis y características asociadas en agricultores de arroz de una región tropical del Perú. Rev perú med exp salud publica. 2014;31(2):195-203.

24. Platts-Mills JA, LaRochelle P, Campos K, Vinetz JM, Gotuzzo E, Ricaldi JN. Seroprevalencia de Leptospirosis en Puente Piedra, Lima en el año 2006. Rev perú med exp salud publica. 2011;28(2):273-6.

25. Céspedes M, Balda L, González D, Tapia R. Situación de la leptospirosis en el Perú 1994-2004. Rev Peru med exp salud publica. 2006;23(1):56-66.

26. Silva-Díaz H, Llatas-Cancino DN, Campos-Sánchez MJ, Aguilar-Gamboa FR, Mera-Villasis KM, Valderrama-Ayén MY. Frecuencia de leptospirosis y características socio-demográficas en pacientes febriles del norte del Perú. Rev Chilena Infectol. 2015;32(5):530-5.

27. Dircio-Montes S, González-Fiqueroa E, María-Saadia V, Elizabeth S, Beatriz $\mathrm{R}$, Víctor MAA, et al. Leptospirosis prevalence in patients. J Trop Med. 2012;201:1-5.

28. de Melo Bezerra LF, Fontes RM, Gomes AM, da Silva DA, Colares JK, Lima DM. Serological evidence of leptospirosis in patients with a clinical suspicion of dengue in the State of Ceará. Brazil Biomedica. 2015;35(4):557-62.

29. Brown MG, Vickers IE, Salas RA, Smikle MF. Leptospirosis in suspected cases of dengue in Jamaica, 2002-2007. Trop Doct. 2010:40:92-4.

30. Ellis T, Imrie A, Katz AR, Effler PV. Underrecognition of leptospirosis during a dengue fever outbreak in Hawaii, 2001-2002. Vector Borne Zoonotic Dis. 2008;8(4):541-7.

31. LaRocque R, Breiman R, Ari M, Morey R, Janan F, Hayes J, et al. Leptospirosis during dengue outbreak, Bangladesh. Emerg Infect Dis. 2005;11(5):766-9.

32. Alva-Urcia C, Aguilar-Luis MA, Palomares-Reyes C, et al. Emerging and reemerging arboviruses: a new threat in eastern Peru. PLoS ONE. 2017:12(11):e0187897.

33. Martins-Luna J, Del Valle-Mendoza J, Silva-Caso W, et al. Oropouche infection a neglected arbovirus in patients with acute febrile illness from the Peruvian coast. BMC Res Notes. 2020;13(1):67.

34. Ricapa-Antay F, Diaz-Melon K, Silva-Caso W, et al. Molecular detection and clinical characteristics of Bartonella bacilliformis, Leptospira spp., and Rickettsia spp. in the southeastern Peruvian Amazon basin. BMC Infect Dis. 2018;18(1):618

35. Pérez Rodríguez NM, Galloway R, Blau DM, et al. Case series of fatal Leptospira spp./dengue virus co-infections-Puerto Rico, 2010-2012. Am J Trop Med Hyg. 2014;91(4):760-5.

\section{Publisher's Note}

Springer Nature remains neutral with regard to jurisdictional claims in published maps and institutional affiliations.

Ready to submit your research? Choose BMC and benefit from

- fast, convenient online submission

- thorough peer review by experienced researchers in your field

- rapid publication on acceptance

- support for research data, including large and complex data types

- gold Open Access which fosters wider collaboration and increased citations

- maximum visibility for your research: over 100M website views per year

At BMC, research is always in progress.

Learn more biomedcentral.com/submissions 